Original Article

\title{
Antibiogram and Heavy Metal Resistance Pattern of Vibrio Alginolyticus Isolated From Asian Seabass (Lates Calcarifer) Hatchery
}

\author{
Lee Seong Wei, Najiah Musa and Wendy Wee \\ Faculty Agro Industry and Natural Resources, Universiti Malaysia Kelantan, Malaysia
}

\begin{abstract}
This paper was described antibiogram and heavy metal resistance pattern of Vibrio alginolyticus isolated from Asian Seabass (Lates calcarifer) hatchery. V. alginolyticus was recognized as a causative agent of vibriosis in Asian seabass and may lead to huge loss to the fish farmer. Therefore, this study was carried out to investigate the suitable of antibiotic to against $V$. alginolyticus. In the present study, a total of 14 antibiotics; oxolinic acid $(2 \mu \mathrm{g})$, ampicillin $(10 \mu \mathrm{g})$, erythromycin $(15 \mu \mathrm{g})$, furazolidone $(15 \mu \mathrm{g})$, lincomycin $(15 \mu \mathrm{g})$, colistin sulphate $(25 \mu \mathrm{g})$, oleandomycin $(15 \mu \mathrm{g})$, doxycycline $(30 \mu \mathrm{g})$, fosfomycin $(50 \mu \mathrm{g})$, florfenicol $(30 \mu \mathrm{g})$, flumequine $(30 \mu \mathrm{g})$, tetracycline $(30 \mu \mathrm{g})$, fosfomycin $(50 \mu \mathrm{g})$ and spiramycin $(100 \mu \mathrm{g})$ as well as four heavy metals; mercury $\left(\mathrm{Hg}^{2}+\right)$, cadmium $\left(\mathrm{Cd}^{2}+\right)$, chromium $\left(\mathrm{Cr}^{6}+\right)$ and copper $\left(\mathrm{Cu}^{2}+\right)$ were applied in the present study. Based on the antibiotic sensitivity test result showed that oxolinic acid the most effective antibiotic in controlling $V$. alginolyticus in which $93.3 \%$ of the present bacterial isolates were sensitive to it. This was followed by furazolidone $(86.7 \%)$, nitrofuratoin $(80.0 \%)$, tetracycline $(73.3 \%)$, doxycycline $(73.3 \%)$ and florfenicol $(73.3 \%)$. On the other hand, all the present bacterial isolates were resistant to lincomycin. In the heavy metal tolerance test, all the present bacterial isolates were resistant to $\mathrm{Hg}^{2}+, \mathrm{Cd}^{2}+, \mathrm{Cr}^{6}+$ whereas only $26.7 \%$ of them were resistant to $\mathrm{Cu}^{2}+$.
\end{abstract}

Key Words: Antibiogram, Heavy metal, Vibrio alginolyticus, Asian Seabass, Lates calcarifer.

Received: 20 February 2011

Accepted: 4 April 2011

\section{Introduction}

Asian seabass, Lates calcarifer (Bloch) is a native fish species in Indo-Pacific region (Greenwood, 1976) and an important species for aquaculture in Asia-Pacific region (Kumar, et al. 2007). It becomes a popular fish species among Malaysian aquaculturist due to high value and

\section{Correspondence:}

Lee Seong Wei

Faculty Agro Industry and Natural Resources, Universiti Malaysia Kelantan, Karung Berkunci 36, Pengkalan Chepa, 16100, Kota Bahru, Kelantan, Malaysia

E-mail: leeseongwei@yahoo.com 
huge demand from local and abroad seafood market. Production of $L$. calcarifer was recorded 20,000 tons per year with the value more than 65 million dollars. However, bacterial diseases were recognized as a significant constraint of the development of Asian seabass culture in worldwide especially vibriosis. Vibriosis was reported as a fatal disease to many marine fish and invertebrate such as shrimp (De la Peña, et al. 1993), crab and lobster (Bowser, et al. 1981), mollusks (Nottage, et al. 1989) and fish (Hustvedt, et al. 1992). Till present, the available information of vibriosis due to Vibrio alginolyticus is still scarce and does not allow prevention and control of the disease in hatchery. Therefore, this study was carried out to provide valuable database for fish farmer in selecting the suitable antibiotic for treatment or prophylactive purpose.

\section{Materials and Methods}

Asian Seabass, Lates calcarifer fingerling with the size 10 to $15 \mathrm{~cm}$ and water samples of $L$. calcarifer nursery tank were collected from commercial Asian Seabass hatchery located at Setiu, Terengganu, Malaysia. The water parameters of the sampling sites were measured using $\mathrm{pH}$ meter (YSI, USA). The temperature, dissolved oxygen, $\mathrm{pH}$ and salinity of the sampling sites were $30.41^{\circ} \mathrm{C}, 6.66 \mathrm{mg} / \mathrm{l}, 8.73$ and $30.31 \mathrm{ppt}$, respectively.

Water samples were collected from $L$. calcarifer fingerling water reservoir tank in four replicates. One millimeter of water sample was serially diluted in sterile physiological saline and plated on two medium; Tryptic Soy Agar (TSA) and Thiosulphate Citrate Bile Salt (TCBS) (Merck, Germany).

Ten diseased $L$. calcarifer fingerling were randomly sampled from nursery tank. Swab was aseptically taken from organs such as eyes, kidney, liver and abdominal fluid of the fish using sterile cotton bud and spread onto TCBS medium.
All the inoculated media were incubated at room temperature for 24 to $48 \mathrm{~h}$. The bacterial colonies that grew on the selective media were further selected for the identification test. The bacterial isolates were identified using conventional biochemical tests (Holt, et al. 1994) and confirmed with commercial identification kit (BBL, USA).

The present isolates $(n=150)$ were cultured in tryptic soy broth (TSB) (Oxoid, England) for $24 \mathrm{~h}$ at room temperature. The bacterial cells were then centrifuged at $14,500 \mathrm{rpm}$ for $5 \mathrm{~min}$ by using minispin (Eppendorf, Germany). The concentration of the bacterial cells were adjusted into 106 colony forming unit (CFU) by using saline and monitored with Biophotometer (Eppendorf, Germany) before being swabbed on the prepared Mueller Hinton agar (Oxoid, England). Antibiotic susceptibility test was conducted according to Kirby-Bauer disk diffusion method using Mueller-Hinton agar (Oxoid, England) (Bauer, et al. 1966). Antibiotics tested including oxolinic acid $(2 \mu \mathrm{g}) ;$ OA 2 , ampicillin $(10 \mu \mathrm{g}) ;$ AMP 10 , erythromycin $(15 \mu \mathrm{g}) ; \mathrm{E} 15$, furazolidone $(15 \mu \mathrm{g})$; FR 15, lincomycin $(15 \mu \mathrm{g})$; MY 15 , colistin sulphate $(25 \mu \mathrm{g})$; CT 25 , oleandomycin $(15 \mu \mathrm{g})$; OL 15 , doxycycline $(30 \mu \mathrm{g})$; DO 30 , florfenicol $(30 \mu \mathrm{g})$; FFC 30, flumequine $(30 \mu \mathrm{g})$; UB 30, tetracycline $(30 \mu \mathrm{g})$; TE 30 , fosfomycin $(50 \mu \mathrm{g})$; FOS 50 and spiramycin $(100 \mu \mathrm{g})$; SP 100 (Oxoid, England). Interpretation of the results namely sensitive (S), intermediary sensitive (I) and resistance $(\mathrm{R})$ was made in accordance to the standard measurement of inhibitory zones in millimeter ( $\mathrm{mm})$.

MAR index (multiple antibiotic resistance) of the present isolates against the tested antibiotics was calculated based on the formula as follows (Sarter, et al. 2007):

MAR index (multiple antibiotic resistance) $=\mathrm{X} /$ (Y x Z)

$\mathrm{X}=$ total of antibiotic resistance case;

$\mathrm{Y}=$ total of antibiotic used in the study;

$\mathrm{Z}=$ total of isolates. 
A MAR index value of equal or less than 0.2 was defined as those antibiotics were seldom or never used for the animal in term of treatment whereas the MAR index value higher than 0.2 is considered that animal have received high risk exposure to those antibiotics.

Heavy metal resistance test was carried out as described by Miranda and Castillo (1998). Bacterial tolerance to four elements of heavy metal, i.e. mercury $\left(\mathrm{Hg}^{2}+\right)$, cadmium $\left(\mathrm{Cd}^{2}+\right)$, chromium $\left(\mathrm{Cr}^{6}+\right)$ and copper $\left(\mathrm{Cu}^{2}+\right)$ was determined by agar dilution method. Overnight bacterial suspension was spread onto plates of TSA medium incorporated with different concentrations of $\mathrm{HgCl}_{2}, \mathrm{CdCl}$, $\mathrm{K}_{2} \mathrm{Cr}_{2} \mathrm{O}_{7}$ and $\mathrm{CuSO}_{4}$ (Fluka, Spain). By twofold dilutions, concentration of both $\mathrm{Cd}^{2}+$ and $\mathrm{Cr}^{6}+$ were ranging from 25 to $400 \mu \mathrm{g} / \mathrm{mL}$ while concentration of $\mathrm{Hg}^{2}+$ and $\mathrm{Cu}^{2}+$ were ranging from 2.5 to $40 \mu \mathrm{g} / \mathrm{mL}$ and 150 to $2400 \mu \mathrm{g} / \mathrm{mL}$, respectively. For the purpose of defining metal resistance, the isolates were considered as resistant if growth was obtained at concentration of $10 \mu \mathrm{g} / \mathrm{mL}\left(\mathrm{Hg}^{2}+\right), 100 \mu \mathrm{g} / \mathrm{mL}\left(\mathrm{Cd}^{2}+\right.$ and $\left.\mathrm{Cr}^{6}+\right)$ and $600 \mu \mathrm{g} / \mathrm{mL}\left(\mathrm{Cu}^{2}+\right)$ (Allen, et al. 1977). The operational definition of tolerance as used in this study was based on the positive bacterial growth when concentration of heavy metals was above the stated concentration for resistance.

\section{Results}

The total plate count of Vibrio alginolyticus from the water sample in the Asian seabass hatchery was $1.3 \times 104$ colony forming unit $(\mathrm{CFU}) / \mathrm{ml}$. In the present study, majority (more than $70 \%$ ) of the present bacterial isolates was found to be sensitive to nitrofuratoin, furazolidone, tetracycline, doxycycline, florfenicol and oxolinic acid (Figure 1). Whereas the percentage of present bacterial isolates sensitive to colistin sulphate, oleandomycin, fosfomycin, erythromycin, lincomycin, ampicillin, flumequine, and spiramycin was ranged from $0 \%$ to $60 \%$. All the present bacterial isolates were found to be resistant to lincomycin. Overall, the total of sensitive case was $50.5 \%$ whereas $40 \%$ and $9.5 \%$ were reported as resistance and intermediary sensitive case. The MAR value of the present study was 0.40. All the present bacterial isolates were found resistant to $\mathrm{Hg}^{2}+, \mathrm{Cd}^{2}+$ and $\mathrm{Cr}^{6}+$. However, $\mathrm{Cd}^{2}+$ was found able to inhibit the growth of $80 \%$ of present bacterial isolates at concentration of $400 \mu \mathrm{g} / \mathrm{mL}$. On the other hand, $73.3 \%$ of the present bacterial isolates were found sensitive to $\mathrm{Cu}^{2}+$.

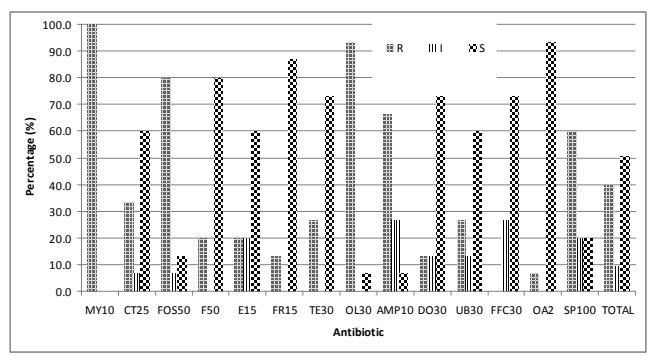

Fig. 1: The Blood Cells in Control Group.

\section{Discussion}

Vibriosis due to Vibrio alginolyticus was recognized as major problem in aquatic animal farming. It was reported attacking various aquatic animals such as tiger shrimp, Penaeus monodon (Lee, et al. 1996), larvae of the catarina scallop, Argopecten ventricosus (Sainz, et al. 1998), gilt-head sea bream (Sparus aurata L.) (Balebona, et al. 1998), shrimp (George, et al. 2005) and giant freshwater prawn (Khuntia, et al. 2008). Till present, there have few reports on $V$. alginolyticus in Malaysia aquaculture. For instance, Idris et al. (2009) reported the virulence of $V$. alginolyticus in Asian seabass. $V$. alginolyticus was also reported in other aquatic animals in Malaysia. For example, mantis shrimp (Musa and Lee, 2008a), diseased seaweed, Gracilaria changii (Musa and Lee, 2008b) and oyster, Crassostrea irdealai (Musa, et al. 2008). As our knowledge, this is first report on $V$. alginolyticus isolated from Asian seabass in Malaysia.

In the present study, nitrofuratoin, furazolidone, tetracycline, doxycycline, florfenicol and oxolinic acid were to be effective in controlling 
V. alginolyticus in Asian seabass. Thus, fish farmer may use these antibiotics for prophylactive and treatment purpose in Asian seabass culture. However, the mentioned antibiotics can not kill all present strains of $V$. alginolyticus. The result of present study showed that oxolinic acid was only found can control up to $90 \%$ of the total present bacterial strains. Therefore, further study should be carried out to find out those antibiotics which can inhibit the growth of all strains of $V$. alginolyticus. For example, in the study of Thakur et al. (2003) reported that of all the bacteria strains of Vibrio spp. including $V$. alginolyticus isolated from moribund shrimp were sensitive to erythromycin, streptomycin and chloramphenicol. Another study of Musa and Lee (2008a) revealed that all strains of $V$. alginolyticus isolated from diseased mantis shrimp were sensitive to chloramphenicol, oxytetracycline and furazolidone.

In additional to antibiotic test, high percentage of heavy metal resistance case was observed among isolated $V$. alginolyticus to the tested heavy metals. This may due the location of our study carried out was surrounded by agricultural activities. Subsequently, the agricultural wastes such as fertilizer consists of heavy metal residues may seep into water source of the Asian seabass hatchery in which our study was conducted. Therefore, bacteria may develop heavy metal resistance gene after exposed to heavy metal residues for a certain period. Till present, there have very few databases on heavy metal resistance pattern of bacteria isolated from aquaculture site in the literature. Therefore, comparison of heavy metal resistance pattern of the present bacterial isolates to the other study can not make.

\section{References}

Allen, D.A., Austin, B. and Colwell, R.R. 1977. Antibiotic resistance patterns of metal-tolerant bacteria isolated from an estuary. Antimicrobial Agents and Chemotherapy. 12 (4), pp. 545-547.
Balebona, M.C., Andreu, M.J., Bordas, M.A., Zorilla, I., Moriñgo, M.A. and Borrego, J.J. 1998. Pathogenicity of Vibrio alginolyticus for cultured gilt-head sea bream (Sparus aurata L.). Applied and Environmental Microbiology. 64 (11), pp. 4269-4275.

Bauer, A.W., Kirby, W.M., Sherris, J.C. and Turck, M. 1966. Antibiotic susceptibility testing by a standardized single disk method. American Journal of Clinical Pathology. 45 (4), pp. 493-496.

Bowser, P.R., Rosemark, R. and Reiner, C.R. 1981. A preliminary report of vibriosis in cultured American lobsters, Homarus americanus. Journal of Invertebrate Pathology. 37 (1), pp. 80-85.

De la Peña, L.D., Tamaki, T., Momoyama, K., Nakai, T. and Muroga, K. 1993. Characteristics of the causative bacterium of vibriosis in the kuruma prawn, Penaeus japonicus. Aquaculture. 115 (1-2), pp. 1-12.

George, M.R., John, K.R., Iyappan, T. and Jeyaseelan, M.J.P. 2005. Genetic heterogeneity among Vibrio alginolyticus isolated from shrimp farms by PCR fingerprinting. Letters in Applied Microbiology. 40 (5), pp. 369-372.

Greenwood, P.H. 1976. A review of the family Centropomidae (Pisces, Perciformes). Bulletin British Museum (Natural History). 29, pp. 1-81.

Holt, J.G., Krieg, N.R., Sneath, P.H.A., Staley, J.T. and Williams, S.T. 1994. Bergey's manual of determinative bacteriology. 9th ed. Lippincott Williams \& Wilkins, Baltimore, MD.

Hustvedt, S.O., Sake, R. and Vassvik, V. 1992. Combating cold-water vibriosis in Atlantic salmon (Salmo salar L.) with oxolinic acid: A case report. Aquaculture. 103 (3-4), pp. 213-219.

Idris, N.I., Al-Haj, N.A., Shamsudin, M.N. and Rahim, R.A. 2009. Evaluation of safe attenuated Vibrio alginolyticus for oral vaccination of Lates calcarifer against vibriosis. Research Journal of Biological Sciences. 4 (4), pp. 509-513. 
Khuntia, C.P., Das, B.K., Samantaray, B.R., Samal, S.K. and Mishra, B.K. 2008. Characterization and pathogenicity studies of Vibrio parahaemolyticus isolated from diseased freshwater prawn, Macrobrachium rosenbergii (de Man). Aquaculture Research. 39 (3), pp. 301-310.

Kumar, S.R., Parameswaran, V., Ahmed, V.P.I., Musthaq, S.S. and Hameed, A.S.S. 2007. Protective efficiency of DNA vaccination in Asian seabass (Lates calcarifer) against Vibrio anguillarum. Fish and Shellfish Immunology. 23 (2), pp. 316-326.

Lee, K.K., Yu, S.R., Chen, F.R., Yang, T.I. and Liu, P.C. 1996. Virulence of Vibrio alginolyticus isolated from diseased tiger prawn, Penaeus monodon. Current Microbiology. 32 (4), pp. 229-231.

Miranda, C.D. and Castillo, G. 1998. Resistance to antibiotic and heavy metals of motile aeromonads from Chilean freshwater. Science of the Total Environment. 224 (1-3), pp. 167-176.

Musa, N. and Wei, L.S. 2008a. Bacteria attached on cultured seaweed Gracilaria changii at Mengabang Telipot, Terengganu. Academic Journal of Plant Sciences. 1 (1), pp. 1-4.

Musa, N. and Wei, L.S. 2008b. Outbreak of vibriosis in Mantis shrimp (Squilla sp.). World Journal of Agricultural Sciences. 4 (2), pp. 137-139.
Musa, N., Wei, L.S., Wee, W., Leong, L.K., Shah, S.M. and Ying, T.H. 2008. Studies of phenotypic and numerical taxonomy of Vibrio spp. isolated from Oyster, Crassostrea iredalei. World Journal of Agricultural Sciences. 4 (2), pp. 189-197.

Nottage, A.S., Sinclair, P.D. and Birkbeck, T.H. 1989. Role of low- molecular-weight ciliostatic toxins in vibriosis of bivalve mollusks. Journal of Aquatic Animal Health. 1 (180), pp. 186.

Sainz, J.C., Maeda-Martínez, A.N. and Ascencio, F. 1998. Experimental vibriosis induction with Vibrio alginolyticus of larvae of the catarina scallop (Argopecten ventricosus $=$ circularis) (Sowerby II, 1842). Microbial Ecology. 35 (2), pp. 188-192.

Sarter, S., Kha Nguyen, H.N., Hung, L.T., Lazard, J. and Montet, D. 2007. Antibiotic resistance in Gram-negative bacteria isolated from farmed catfish. Food Control. 18 (11), pp. 1391-1396.

Thakur, A.B., Vaidya, R.B. and Suryawanshi, S.A. 2003. Pathogenicity and antibiotic susceptibility of Vibrio species isolated from moribund shrimps. Indian Journal of Marine Sciences. 32 (1), pp. 71-75. 